\title{
Erratum to: A Biography of Kenneth C. Land: Pioneer in Quality of Life and Social Indicators Research
}

\author{
Vicki L. Lamb
}

Published online: 19 August 2014

(C) Springer Science+Business Media Dordrecht and The International Society for Quality-of-Life Studies (ISQOLS) 2014

\section{Erratum to: Applied Research Quality Life (2014) \\ DOI 10.1007/s11482-014-9337-Z}

The sub-sections in the reference list were unfortunately misplaced and the photo of Kenneth C. Land was missing in the original publication. The correct reference list and photo are presented here.

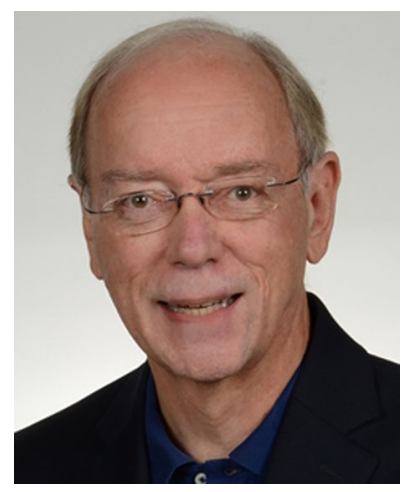

\section{Selected References}

\section{Edited Books}

Juster, F. T., \& Land, K. C. (Eds.). (1981). Social accounting systems: Essays on the state of the art. New York: Academic Press, Studies in Population Series.

Land, K. C. (Ed.). (2012). The well-being of America's children: Developing and improving the child and youth well-being index. New York: Springer.

The online version of the original article can be found at http://dx.doi.org/10.1007/s11482-014-9337-z.

V. L. Lamb $(\bowtie)$

North Carolina Central University, 1801 Fayetteville St, Durham, NC 27707, USA

e-mail: vlamb@nccu.edu 
Land, K. C., \& Spilerman, S. (Eds.). (1975). Social indicator models. New York: Russell Sage.

Land, K. C., \& Schneider, S. H. (Eds.). (1987). Forecasting in the social and natural sciences. Boston: D. Reidel Publishing Company.

Land, K. C., Michalos, A. C., \& Sirgy, M. J. (Eds.). (2012). Handbook of social indicators and quality-of-life research. New York: Springer.

\section{Peer-Reviewed Publications}

Evans, M. D., Felson, M., \& Land, K. C. (1980). Developing social indicator research on the military in American society. Social Indicators Research, 8, 81-102.

Hagerty, M. R., \& Land, K. C. (2007). Constructing summary indices of quality of life: a model for the effect of heterogeneous importance weights. Sociological Methods and Research, 35(May), 455-496.

Hagerty, M. R., Cummins, R. A., Ferriss, A. L., Land, K. C., Michalos, A. C., Peterson, M., Sharpe, A., Sirgy, J., \& Vogel, J. (2001). Quality of life indexes for national policy: review and agenda for research. Social Indicators Research, 55(July), 1-96.

Land, K. C. (1971). On the definition of social indicators. The American Sociologist, 6(November), 322-325.

Land, K. C. (2001). Models and indicators. Social Forces, 80, 381-410. Ken's Presidential Address to the Southern Sociological Society.

Land, K. C., \& Felson, M. (1976). A general framework for building dynamic macro social indicator models: including an analysis of changes in crime rates and police expenditures. American Journal of Sociology, 82(November), 565-604.

Land, K. C., \& Felson, M. (1977). A dynamic macro social indicator model of changes in marriage, family, and population in the United States: 1947-74. Social Science Research, 6(December), 328-362.

Land, K. C., Lamb, V. L., \& Mustillo, S. K. (2001). Child and youth well-being in the United States, 19751998: some findings from a new index. Social Indicators Research, 56(December), 241-320.

Land, K. C., Lamb, V. L., Meadows, S. O., \& Taylor, A. (2007). Measuring trends in child well-being: an evidence-based approach. Social Indicators Research, 80(January), 105-132.

Land, K. C., Lamb, V. L., \& Zheng, H. (2011). How are the kids doing? How do we know? Recent trends in child and youth well-being in the United States and some international comparisons. Social Indicators Research, 100(February), 463-477.

Lee, J., Lamb, V. L., \& Land, K. C. (2009). Composite indices of changes in child and youth well-being in the San Francisco Bay Area and the State of California, 1995-2005. Child Indicators Research, 2(December), 353-374.

O’Hare, W. P., Mather, M., Dupuis, G., Land, K. C., Lamb, V. L., \& Fu, Q. (2013). Analyzing differences in child well-being among U.S. states. Child Indicators Research, 6(June), 401-413.

Meadows, S. O., Land, K. C., \& Lamb, V. L. (2005). Assessing Gilligan versus Sommers: gender-specific trends in child and youth well-being in the United States, 1985-2001. Social Indicators Research, 70(January), 1-52.

Pampel, F. C., Land, K. C., \& Felson, M. (1977). A social indicator model of changes in the occupational structure of the United States: 1947-74. American Sociological Review, 42(December), 951-964.

\section{Invited Chapters and Other Contributions to Volumes (not edited by Ken Land)}

Lamb, V. L., \& Land, K. C. (2013). Methodologies used in the construction of composite child well-being indices. In A. Ben-Arieh, F. Casas, I. Frones, \& J. Korbin (Eds.), Handbook of child well-being (pp. 2739-2755). New York: Springer.

Lamb, V.L., \& Land, K. C. (2014). Worldwide view of child well-being. In W. Glatzer (Ed.), Global handbook of well-being and quality of life. New York: Springer, forthcoming.

Lamb, V. L., Land, K. C., Meadows, S. O., \& Traylor, F. (2005). Trends in African-American child well-being: 1985-2001. In V. C. McLoyd, N. E. Hill, \& K. A. Dodge (Eds.), African American family life: Ecological and cultural diversity (pp. 45-77). New York: Guilford Publications. 